DOI https://doi.org/10.30525/978-9934-26-000-1-4

\title{
ДИСКУРС НАЦІОНАЛЬНОЇ ІДЕНТИЧНОСТІ В ПУБЛІЦИСТИЦІ ЮРІЯ ШЕВЕЛЬОВА
}

\author{
Загоруйко Н. А. \\ кандидат філологічних наук, \\ старший викладач кафедри журналістики \\ Кам'янеиь-Подільський національний університет імені Івана Огієнка \\ м. Кам'янець-Подільський, Хмельницька область, Украӥна
}

Феномен культури 20-х років мав доленосне значення для Юрія Шевельова - етнічного німця, який з дому по батькові мав прізвище Шнейдер, а по матері Медер, адже він був безпосереднім свідком того, як Україна виходила на європейський рівень, а однією 3 найбільших удач свого життя вважав те, що бачив прем'єру «Маклени Граси»: «Є місця, - зазначав Юрій Шерех, - відвідання яких сповнюють гордістю за людину, людський дух, навіть якщо ставитися до людини взагалі скептично. Для мене такими місцями були Акрополь у Греції, Нара в Японії, Тадж Магал в Індії, Ужмаль у Мексиці. I такі моменти. До цих належить вистава “Маклени Граси”» [4, с. 260]. Ю. Шевельов пригадував, що «Маклена» пройшла дванадцять разів й вважав іiі заповітом Л. Курбаса українському театрові.

У спогадах «Я - мене - мені ...» Ю. Шевельов пояснює, чому його батько царський генерал Володимир Карлович Шнейдер у 1916 році змінив прізвище: «Батько боляче відчував, вірою й правдою служачи Росії, підозри, які спадали на нього в армійських колах за його німецьке походження. Запало рішення змінити прізвище й навіть по батькові. Шукали прізвища [...] воно мало б бути виразно російське без крамоли й зради. Вибрали Шевельов, по батькові - Юрійович».

У «Інтродукції» до «Вибраного листування на тлі доби» О. Забужко, апелюючи до його спогадів «Я - мене - мені», виокремлює два ключові етапи у кристалізації національної ідентичності Ю. Шевельва: спочатку його захопили високі осяги української культури - «Березіль» Л. Курбаса, писання М. Хвильового, вірші П. Тичини, проза Ю. Яновського, відкриття Т. Шевченка в оригіналі, а особливо, на перших кроках, відкриття Лесі Українки з іiі поєднанням європейськости 3 українськістю: «Бо я не був селюк, і українськість найбільше промовляла до мене через європейськість». Шерех припускає, що вирішального значення це не мало, якби «не пізніше, вже від кінця двадцятих років почате, а в тридцятих доведене до гротескної трагедії переслідування українців і української культури. Тепер українці були перетворені на те, що англомовні народи окреслюють словом underdog, і тепер відійти від 
того, чим я захоплювався в двадцятих роках, було б ганьбою й злочином перед самим собою. [...] Коли запроваджувано пашпорти, треба було визначити для пашпорта свою національність, я усвідомлював, що було б куди безпечніше написати росіянин, і це цілком залежало від мого вільного вибору, але після недовгих вагань я вибрав - украӥнець». Як бачимо, ключову роль зіграли, говорячи словами С. Павличко, не лише факт небувалого спалаху творчої активності українських літераторів, а й більшовицька розправа над ними. Юрій Володимирович зізнавався, що тоді у нього витворився комплекс приналежності до української стихії й культури та комплекс самостійництва: «Я занадто багато вклав себе в цю культуру, щоб пристати на їі знищення, а єдиний рятунок від такої перспективи була самостійність і викорінення російського з України».

Проте - вище наведений фрагмент - це лише одне з багатьох свідчень Юрія Шевельова, бо тема його вибору - лейтмотив його спогадів та есеїстики. Аналізуючи своє минуле, порівнюючи факти свого життя, він щоразу повертається до цієї теми: «Коли я дивлюся на своє життя сьогодні і зважую причини мого вибору, мені здається, що найвирішальнішим було все-таки не майбутнє, а минуле. I мені здається, що українськість завжди була в моїй родині. Так, це парадоксально. I батько й мати німецького коріння. Обидва виховані в Петербурзі. Вони жили в російській культурі і в російській мові. Так вони виховували дітей, зокрема мене. [...] I все-таки, все-таки... Українськість якось ірраціонально жила в Харкові, жила в матері і в сестрі. Тисячею дрібниць вона входила в життя [...] Майже ніщо 3 того не було на поверхні, і все-таки воно існувало. С в німців слово Sein - буття, і $€$ добре неперекладне слово Dasein - бути в певному часі і місці, бути тут, бути навколо, оточувати. I - додам - бути любленим, бути своїм. Україна була своєю, 3 iї пейзажем, 3 iі людьми, 3 іï білими (тоді!) хатками» [4, с. 86-87]. Саме тому свій вибір називав шляхом до Дамас$\kappa y$, який був якоюсь мірою вторований матір'ю. На цьому аспекті О. Забужко у вже згаданій «Інтродукції» робить особливий наголос [1, c. 33-35]. Також важливу роль у цьому плані відіграло блискуче домашнє виховання та освіта, яку він отримав ще за «старими стандартами». Зауважував, що у період, на який припало формування його світогляду, «староімперська школа розхиталась, а нова, комуністична, ще була в сповитку», а на всі впливи мав вироблену свою протиотруту. Про себе говорив: «Я був нережимним». Про стосунки між людьми зауважував: «Було в радянській людині того часу специфічне шосте відчуття: відчуття порядности й унутрішньої не-радянськости (що не конче означає протирадянськости) зустрічного».

Мемуаристика Ю. Шереха дозволяє стверджувати, що його ідентифікація з українством була зумовлена глибокими внутрішніми пере- 
живаннями. Ю. Шевельов казав, що можна бути ідейним ворогом певної системи й водночас психологічно бути її частинкою.

Впадає в око, що Ю. Шевельов, описуючи становлення нового радянського ладу, яке назвав вступом до масового суспільства, звертається до вчення Х. Ортеги-і-Гасета про маси, якого зараховував до числа своїх вчителів. Шерех говорить про «знелюднення людини», позбавлення іiі індивідуальних рис, бо індивід має підпорядковуватись «велінням і хотінням мас», а до гідності людини не мають ніякого розуміння. Підкреслює, що основою філософії ленінізму стала «безглуздість усього людського і людиною створеного». Крізь призму власного досвіду Шевельов порушує тему конфлікту «ніжношкірої людини-особистости 3 тими грубошкірими масами, яких революція винесла на поверхню життя». У «Бунті мас» іспанський філософ констатує: «юрба раптом стала видима і влаштувалась на кращих місцях у суспільстві» [2, с. 17].

Говорячи про духовну катастрофу ХХ століття, Шерех підкреслює, що поодинока людина в радянській системі не мала ніякої вартості «це була ера безвартісності людського життя і здобутків людських культурних цінностей», а нову людину мало виховувати «псевдомистецтво штампа й спрощених почувань». Шерех констатував наступ «організованої пересічности» та 3 власного досвіду знав, що таке «під'юджування посередностей проти талантів», особливо боляче переживаючи цькування Л. Курбаса. Іспанський філософ говорив: «Маса розчавлює під собою все, що відмінне, незвичайне, індивідуальне, кваліфіковане й добірне».

Позиція Шереха було зумовлена внутрішнім спротивом радянській владі, яка була заснована на терорі та нищенні особистості. Опинившись, за висловом Р. Корогодського, в магнетному полі «пожнив'я років чистого гуманізму», Юрій Володимирович не міг і не хотів ставати частиною системи: «Моє давнє внутрішнє неприйняття радянщини примхливою психологічною грою ввійшло в асоціяції зі станом української культури: іiі женуть і переслідують, значить - ми спільники» [4, с. 192]. У мемуарах підкреслює, що не хотів належати і до росіян: «Росіяни були панами, я волів бути з андердогами. Українці були в потоптанні, але і в ставанні» [4, с. 179]. Перше викликало в нього симпатію, друге - бажання рухатися разом. Поза тим наголошує: «Можливо, якби не українізаційна політика тих часів, я пішов би за інерцією свого середовища в його зверхніх виявах і став би російським діячем» [4, с. 179].

В одному 3 есеїв Ю. Шевельов розглядає лексичне значення англійського слова «privacy», зауважуючи, що англо-українські словники пропонують спотворений переклад: «самотність, відокремленість, відлюдність, безлюдність», тоді як головне значення - «право бути собою, належати собі, мати свій дім - свій храм, мати свій світогляд, свої манери» [3, с. 346]. Він слушно підкреслює, що протилежний до 
privacy - «ие comтипіs, куди належить $i$ комунізм, комуна, компартія». За цим простим словесним аналізом проглядається не лише квінтесенція полярних ідеологій, але й його власне відмежування, бо відкинення радянської системи для Шевельова також означало відстояти своє право на privacy - мати свою маленьку privacy. I хоча у ті часи було важко мати свій дім (після квартирного «ущільнення» у їхньому помешканні для нього з матір'ю залишилось вісім квадратних метрів) - право належати собі він залишив за собою, бо в родині була релігія науки й книжки, були мистецтво, театр, музика. Шевельов зізнавався, що у ті роки його рятували студії в О. Білецького, Л. Булаховського, А. Шамрая.

Відтак, конфлікт Ю. Шевельова з системою, який головно виник у морально-психологічній площині, згодом став оновою світогляду, залишивши глибокий слід у його інтелектуальній спадщині як мислителя: «вся діяльність Шереха, - говорив він, - в певному аспекті була історією визволення від цього ладу» [3, с. 28]. Юрій Шерех протиставляє країні червоного терору країну культурного ренесансу 20 -х років, країну, в якій українськість промовляла до нього через європейськість.

\section{Лiтература:}

1. Забужко О., Шевельов Ю. Вибране листування на тлі доби : 1992-2002. К. : Висока Полиця, ВД Факт, 2011. 504 с.

2. Ортега-і-Гассет Х. Вибрані твори / Хосе Ортега-і-Гассет ; [перекл. $з$ іспанської В. Бургардта, В. Сахна, О. Товстенко]. К. : Основи, 1994. $420 \mathrm{c}$.

3. Шевельов Ю. 3 історії незакінченої війни / Юрій Шевельов ; [упоряд. О. Забужко, Л. Масенко]. К. : Видавничий дім «КМ Академія», 2009. $471 \mathrm{c}$.

4. Шерех Ю. В. Я - мене - мені... (і довкруги). Спогади. 1. В Україні. Харків : Фоліо, 2012. 475 с. 